\title{
Effect of Phytohormones and Chemical Inhibitors on Pathogenesis-related Genes Identified by Differential Hybridization in Rice Suspension Culture Cells
}

\author{
Sang Gon Kim ${ }^{2,4}$, Jingni Wu' ${ }^{1}$, Yiming Wang ${ }^{1}$, Ethan E White ${ }^{4}$, Young Whan Choi ${ }^{5}$, Keun-Ki Kim ${ }^{6}$, \\ In Soo Choi ${ }^{7}$, Yong Cheol Kim ${ }^{7}$, Sun-Hyung Kim ${ }^{8}$, Kyu Young Kang ${ }^{1,2,3 *}$ and Sun Tae Kim ${ }^{7 *}$ \\ ${ }^{1}$ Division of Applied Life Science (BK21 Program), Gyeongsang National University, Jinju 660-701, Korea \\ ${ }^{2}$ Environmental Biotechnology National Core Research Center, Gyeongsang National University, Jinju 660-701, Korea \\ ${ }^{3}$ Plant Molecular Biology and Biotechnology Research Center, Gyeongsang National University, Jinju 660-701, Korea \\ ${ }^{4}$ Department of Chemistry and Biochemistry, Baylor University, Waco, TX 76798-7348, USA \\ ${ }^{5}$ Department of Horicultural Bioscience, Pusan National University, Miryang 627-706, Korea \\ ${ }^{6}$ Department of Life Science and Environmental Biochemistry, Pusan National University, Miryang 627-706, Korea \\ ${ }^{7}$ Department of Plant Bioscience, Pusan National University, Miryang 627-706, Korea \\ ${ }^{8}$ Department of Environmental Horticulture, University of Seoul, Seoul 130-743, Korea \\ (Received on August 21, 2010; Accepted on November 10, 2010)
}

In order to study disease resistance mechanisms in rice against the rice blast fungus Magnaporthe grisea, we screened fungal elicitor-responsive genes from rice suspension-cultured cells treated with fungal elicitors employing differential hybridization (DH). By DH screening, 31 distinct rice clones were isolated and a majority of them were full-length cDNAs encoding pathogenesisrelated (PR) genes. Sixteen of the 31 genes were upregulated at 4,8 , and $12 \mathrm{~h}$ following fungal elicitor treatment. To elucidate the effect of signal molecules and biotic elicitors on the regulation of rice defense genes, we further characterized the transcriptional expression patterns of representative isolated PR genes; OsGlu1, OsGlu2, OsTLP, OsRLK, and OsPR-10, following treatment with fungal elicitor, phytohormones, cycloheximide, and inhibitors of protein phosphorylation. Jasmonic acid (JA) induced transcriptional expression of OsGlu1, OsTLP, and OsRLK, but not of OsGlu2 and OsPR-10 at any of the tested time points. Salicylic acid (SA) and abscisic acid weakly induced the expression of $O S T L P$ and $O S R L K$. SA showed an antagonistic effect with fungal elicitor and JA. Cycloheximide suppressed all these genes upon elicitor treatment, except for OsGlu2. Staurosporine only induced the expression of OsRLK. Application of calyculin A strongly induced OsRLK expression, but suppressed the expression of OsGlu2. Our study yielded a number of PR genes that play a role in defense mechanisms against the rice blast fungus, as well as contribute towards the elucidation of crosstalk between phytohormones and other modifications during defense signaling.

\footnotetext{
*Corresponding author.

Phone) +82-55-350-5505, FAX) +82-55-350-5509

E-mail) stkim71@pusan.ac.kr; Kykang@gnu.ac.kr
}

Keywords : differential hybridization, elicitor, pathogenesisrelated genes, rice suspension-cultured cells

Magnaporthe grisea, which is the causal agent of rice blast, causes one of the most devastating diseases in rice (Hamer and Talbot, 1998; Kim et al., 2001), and is a very serious problem in rice-growing regions of the world (Talbot, 2003). Every year, rice blast epidemics have the potential to adversely affect rice yields which feed over sixty million people globally. To overcome this disease, identifying genes that can defend against fungal biotic stress would be of great value. This can be achieved by investigating various defense mechanisms in rice such as changes in ion fluxes, reactive oxygen species, phytoalexins, pathogenesisrelated (PR) genes and phytohormones (Dixon and Lamb, 1990; Shinozaki and Yamaguchi-Shinozaki, 2000; Staskawicz et al., 1995). Studying host gene expression levels in response to $M$. grisea infection is critical to understand the regulation of defense mechanisms. Even though many disease resistance genes have been cloned in rice, very little has been reported about crosstalk with fungal elicitor and/or phytohormones in rice.

The signal transduction network that is regulated PR genes is comprised of several interacting pathways. The salicylic acid (SA) and jasmonic acid (JA) pathway that is induced by pathogens results in the production of endogenous SA and JA, which then act as signal molecules leading to the transcriptional induction of several PR genes (Kunkel and Brooks, 2002; Thomma et al., 2001). However, JA and SA showed an antagonistic role in defense regulation and both of them are essential for pathogen resistance (Truman et al., 2007). Recently, it was reported that SA strongly suppressed the JA-dependent 
pathway in Arabidopsis (Koornneef et al., 2008). ABA is also an essential hormone in plant resistance to pathogens, affecting JA biosynthesis as well as activating aspects of the defense response (Adie et al., 2007), and consequently playing an important role in development, biotic and abiotic stresses (Acharya et al., 2009; Bari et al., 2009; Seo et al., 2009).

In previous studies, several PR proteins and genes were investigated by proteomics and SAGE analysis, respectively, in both rice leaves and suspension-cultured cells (SCCs) (Kim et al., 2003b, 2004a, 2008a). The PR genes tested showed a different response to pathogen attack and hormone treatments (Kim et al., 2003b, 2004a). However, despite studies on these proteins or genes, the molecular mechanisms underlying the elicitor-mediated signal transduction pathway is not yet fully understood in rice SCCs. The SCCs system has been developed to monitor the change of gene or protein expression levels under selected stresses compared to the whole plant.

In this report, phage-based cDNA differential hybridization $(\mathrm{DH})$ in combination with isotope labeling enabled the successful isolation of 31 genes induced by fungal elicitor in rice SCCs. Among the 31 isolated genes, the transcript levels of 16 genes were increased by treatment with fungal elicitor. We also investigated the crosstalk between fungal elicitor, phytohormones, and chemical inhibitors through transcriptional analysis of OsPR-10, OsGlu1, OsGlu2, OsTLP, and OsRLK in rice SCCs. Fungal elicitor, phytohormones, and chemical inhibitors were applied to rice SCCs independently or in combination to confirm the regulation of PR genes by Northern blot analysis.

\section{Materials and Methods}

Plant materials. Mature rice seeds (Oryza sativa L.cv. Jinheung) were obtained from the National Yeongnam Agricultural Experimentation Station (Miryang, Korea). The dehulled seeds were sterilized in $70 \%$ ethanol for 10 min and $3 \%$ sodium hypochlorite for $30 \mathrm{~min}$, followed by extensive rinsing in sterile water 5 times. Sterilized seeds were placed on N6 medium to induce callus (Ohira et al., 1973), which were subcultured at weekly intervals in N6 suspension medium with shaking at $100 \mathrm{rpm}$ in the dark at $25^{\circ} \mathrm{C}$. All treatments on SCCs were performed after 2-3 days following subculture in fresh medium.

Preparation of fungal elicitor. Conidia were prepared according to the method described by Kim et al. (2004b). Mycelia of rice blast fungus (race KJ401), which is incompatible in the rice cv. Jinheung, was used. Briefly, the mycelia was macerated, homogenized in $50 \mathrm{mM}$ sodium acetate buffer ( $\mathrm{pH} 4.5$ ), sonicated, and centrifuged. The pellet was homogenized again in $0.1 \mathrm{M}$ borate buffer $(\mathrm{pH}$ 8.8 ), autoclaved, and the supernatant was extensively dialyzed in distilled water at $4{ }^{\circ} \mathrm{C}$ and freeze-dried. Reducing sugar was determined by the dinitrosalicylic acid method using glucose as the standard. The rice calli (approx. 500 $\mathrm{mg}$ fresh weight) were suspended in $5 \mathrm{ml}$ of $\mathrm{N} 6$ suspension medium in six-well plates and subsequently treated with 50 $\mathrm{mg} / \mathrm{ml}$ (glucose equivalent) fungal elicitor.

Rice callus $\lambda$ ZAP II cDNA library construction. Fourday old rice SCCs were treated with fungal elicitor of 50 $\mathrm{mg} / \mathrm{ml}$ for $8 \mathrm{~h}$ and harvested by filtration and frozen in liquid nitrogen. Total RNA was isolated by the phenol/ chloroform extraction method (Kim et al., 2008a). Poly (A) mRNA was purified on oligo-d(T) cellulose columns (Amersham, USA). The mRNA was used to generate a cDNA library in the $\lambda$ ZAP II vector (Stratagene, USA) following the manufacturer's specification.

Phage-based cDNA differential hybridization (DH) screening. To isolate fungal elicitor-induced genes, the phagebased cDNA library from mRNA extracted from SCCs treated with fungal elicitor was plated on $E$. coli XL1-Blue MRF to a density of 2-500 plaques per petri dish and blotted on a nitrocellulose membrane from the library. The nitrocellulose membranes were hybridized with ${ }^{32} \mathrm{P}$-labeled control cDNA probe. For decreasing the false positives, hybridization was repeated with ${ }^{32} \mathrm{P}$-labeled control cDNA probe using isolated negative plaques. These isolated negative plaques were subjected to in vivo excision to produce the pBluescript $\mathrm{SK}^{+}$plasmid clones (Fig. 1).

Chemical treatments. The callus was treated with $50 \mu \mathrm{g} /$

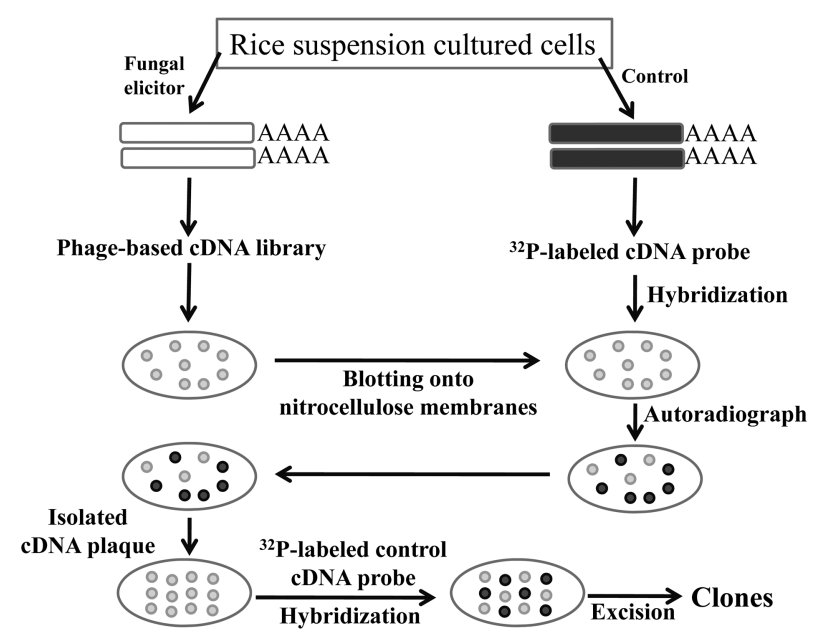

Fig. 1. Schematic diagram of phage-based cDNA differential hybridization $(\mathrm{DH})$. 
$\mathrm{ml}$ fungal elicitor, $250 \mu \mathrm{M} \mathrm{JA}, 5 \mathrm{mM}$ SA, or $200 \mu \mathrm{M}$ ABA. Samples were harvested at 4 and $8 \mathrm{~h}$ after treatment. Solutions of cycloheximide $(1 \mu \mathrm{M})$, staurosporine $(1 \mu \mathrm{M})$, calyculin $\mathrm{A}(1 \mu \mathrm{M})$, and $\mathrm{A} 23187(20 \mu \mathrm{M})$ were prepared in final $0.01 \%$ dimethylsulfoxide (DMSO) and incubated with the SCCs for $1 \mathrm{~h}$ before treatment with fungal elicitor.

Northern blot analysis. Aliquots of total RNA $(20 \mu \mathrm{g})$ were separated on a $1.2 \%(\mathrm{w} / \mathrm{v})$ formaldehyde-agarose gel and transferred onto a nylon membrane (Hybond- $\mathrm{N}^{+}$, Amersham, USA). After transfer, RNA was cross-linked to the nylon membrane by UV, and used in Northern blot analysis. Hybridization was carried out with ${ }^{32} \mathrm{P}$-labeled cDNA probe by using the Prime-a-Gene labeling system (Promega, Madison, USA). After hybridization in $65^{\circ} \mathrm{C}$ for $12 \mathrm{~h}$, the membranes were washed with $2 \times \mathrm{SSC}$ containing
$0.1 \%$ (w/v) SDS for $30 \mathrm{~min}$, followed by additional washing with $0.2 \times \mathrm{SSC}$ containing $0.1 \%(\mathrm{w} / \mathrm{v})$ SDS for 10 min. The signals were detected after exposure on X-ray film (Fuji, Japan) for 3 days at $-80^{\circ} \mathrm{C}$.

\section{Results and Discussion}

Isolation of rice blast fungal elicitor-induced genes by phage-based cDNA DH library. To isolate the fungal elicitor-induced genes, we used a phage-based cDNA DH library. First, we optimized the cDNA library DH conditions. Nitrocellulose membranes blotted from fungal elicitor treated cDNA library plaques were hybridized with ${ }^{32} \mathrm{P}$-labeled cDNAs generated from untreated rice SCCs. To improve the efficiency of isolating PR genes, we repeated hybridization with ${ }^{32} \mathrm{P}$-labeled control cDNAs after isolat-

Table 1. Rice blast fungal elicitor-induced genes from rice SCCs by phage-based cDNA DH.

\begin{tabular}{|c|c|c|c|}
\hline Clone No. & Corresponding gene & Accession no. & Source \\
\hline Cal & Phospholipase D & BAA19466 & O. sativa \\
\hline $\mathrm{Ca} 2$ & Receptor-like protein kinase (OsRLK) & AY911869 & O. sativa \\
\hline $\mathrm{Ca} 3$ & Myb-related transcription factor-like protein & NM_001062798 & O. sativa \\
\hline $\mathrm{Ca} 4$ & Sucrose synthase 2 & NM_001063582 & O. sativa \\
\hline $\mathrm{Ca} 5$ & Aspartate aminotransferase & D14673 & O. sativa \\
\hline $\mathrm{Ca} 6$ & Pathogen-related protein $10($ OsPR-10) & AF416604 & O. sativa \\
\hline $\mathrm{Ca} 7$ & Thaumatin-like protein (OsTLP) & X68197 & O. sativa \\
\hline $\mathrm{Ca} 8$ & Putative cinnamoyl-CoA reductase & AP003018 & O. sativa \\
\hline $\mathrm{Ca} 9$ & Beta 1,3-glucanase (OsGlu1) & AB027428 & O. sativa \\
\hline Ca10 & L-allo-threonine aldolase & AK099280 & O. sativa \\
\hline Call & Proteophosphglycan & AK 105557 & O. sativa \\
\hline Ca12 & ATP/ADP translocator & D12637 & O. sativa \\
\hline Ca13 & Putative polyprotein & AY360388 & O. sativa \\
\hline Ca14 & Senescence-associated protein & NM_001069782 & O. sativa \\
\hline Ca15 & ATP-binding protein of $\mathrm{ABC}$ transforter & NM_00105703 & O. sativa \\
\hline Ca16 & Beta 1,3-glucanase (OsGlu10) & AF030167 & O. sativa \\
\hline $\mathrm{Ca} 17$ & Putative GTP-binding protein & AJ307662 & O. sativa \\
\hline Ca18 & EREBP-like protein & AF190770 & O. sativa \\
\hline Ca19 & Zinc-induced protein & AF323612 & O. sativa \\
\hline $\mathrm{Ca} 20$ & Cytosolic glutamine synthethase & AB037595 & O. sativa \\
\hline $\mathrm{Ca} 21$ & MAP kinase MAPK2 & AF241166 & O. sativa \\
\hline $\mathrm{Ca} 22$ & Beta 1,3-glucanase (OsGlu2) & AB027430 & O. sativa \\
\hline $\mathrm{Ca} 23$ & Oryzain alpha precursor & D90406 & O. sativa \\
\hline $\mathrm{Ca} 24$ & Small GTP-binding protein & AY029301 & O. sativa \\
\hline $\mathrm{Ca} 25$ & Sucrose transporter & AF280050 & O. sativa \\
\hline $\mathrm{Ca} 26$ & Nucleoside diphosphate kinase & D16292 & O. sativa \\
\hline $\mathrm{Ca} 27$ & Cationic peroxidase & AF019743 & O. sativa \\
\hline $\mathrm{Ca} 28$ & Putative auxin response factor 1 & AF140228 & O. sativa \\
\hline $\mathrm{Ca} 29$ & NLS receptor & $\mathrm{AB} 004660$ & O. sativa \\
\hline $\mathrm{Ca} 30$ & Phenylalanine ammonia-lyase & NM_001059861 & O. sativa \\
\hline $\mathrm{Ca} 31$ & MAP kinase BIMK1 & AF332873 & O. sativa \\
\hline
\end{tabular}




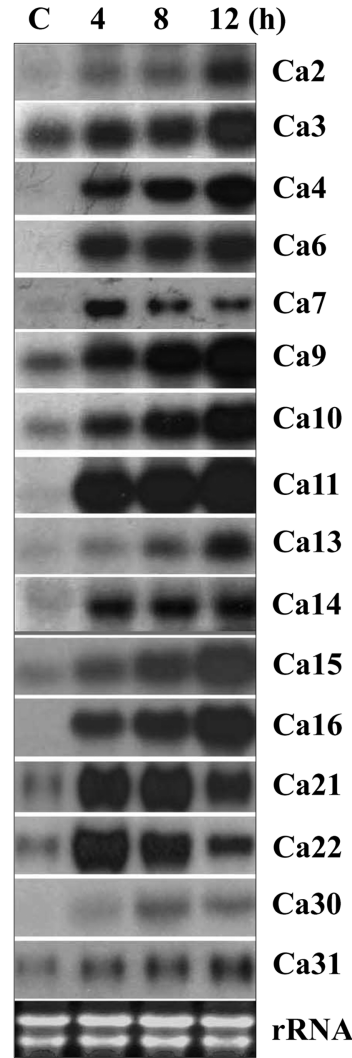

Fig. 2. Time-course accumulation of 16 rice genes in response to fungal elicitor in rice SCCs. Northern blots were prepared from total RNAs $(20 \mu \mathrm{g}$ each lane) isolated from water-treated (control) and rice blast fungal elicitor $(50 \mu \mathrm{g} / \mathrm{ml}$ glucose equivalents, 4,8 , and $12 \mathrm{~h}$ post-inoculation) in rice suspension cells and hybridized individually with 16 distinct cDNA clones.

ing negative plaques as shown in Fig. 1. Among 10,000 cDNA library plaques, 31 clones which were induced by fungal elicitor were isolated. Then we sequenced the clones and conducted a homology search using BLAST, NCBI. Sequence analysis indicated that these 31 clones belonged to pathogen-related (PR) genes or other relatively abundant genes (Table 1). The use of phage-based cDNA DH technology allowed us to successfully isolate a large number of PR genes induced by rice fungal elicitor.

Northern blot analysis of fungal elicitor-induced genes. To confirm expression patterns, Northern blot analyses were performed individually with each of the 31 genes. Of these, 16 genes had highly elevated and rapidly induced transcript levels at 4,8 , and $12 \mathrm{~h}$ after treatment with fungal elicitor (Fig. 2). Representative fungal elicitor-induced genes were receptor-like protein kinase $(O s R L K, \mathrm{Ca} 2)$, pathogen-related protein $10(O s P R-10, \mathrm{Ca})$, thaumatinlike protein (OsTLP, Ca7), $\beta$-1,3-glucanase 1 (OsGlul, Ca9), $\beta$-1,3-glucanase 10 (OsGlu10, Ca16), and $\beta-1,3-$ glucanase 2 (OsGlu2, Ca22) (Table 1, Fig. 2).

In previous reports, OsRLK and OsTLP were identified as secreted proteins in rice SCCs treated with the rice blast fungus Magnaporthe grisea and its elicitor using secretome analysis (Kim et al., 2009) and also highly induced in the incompatible interaction, compared to the compatible interaction (Kim et al., 2004a). OsPR-10 was expressed in developmental tissues, including the flower and root (Kim et al., 2008b) and was also expressed under environmental stresses such as rice blast fungus/fungal elicitor, wounding, senescence, and phytohormone application (Kim et al., $2003 b, 2004 a, 2008 b)$. Finally, plant $\beta-1,3$-glucanases are extracellular hydrolytic enzymes found widely in many plant species and were induced by various pathogens and phytohormones as well as during developmental events (Hwang et al., 2007). In addition, based on 2-DE and Northern blot analyses, OsGlu1 and OsGlu2 were constantly induced both in the resistant and susceptible response against rice blast fungus attack in rice leaves (Kim et al., 2004a). However, despite studies of these proteins, there is no information available on the modulation of these PR genes in signal transduction pathways in SCCs.

Rice PR genes were differentially regulated by fungal elicitor, JA, SA, and ABA. To understand the signal transduction pathways that lead to activation of the PR genes, we examined the effect of a fungal elicitor and the phytohormones JA, SA, and ABA on the transcriptional expression of OsPR-10 (Ca6), OsGlu1 (Ca9), OsGlu2 (Ca22), OsRLK (Ca2), and OsTLP (Ca7) in SCCs by Northern blot analysis (Fig. 2 and Fig. 3). The possible interactions between elicitor and phytohormones on the transcript levels of PR genes were investigated by applying elicitor and/or phytohormones, either independently or in various combinations to rice SCCs (Fig. 3). Northern blot analysis showed that fungal elicitor strongly activated transcriptional levels of these PR genes within $8 \mathrm{~h}$ (Fig. 2 and Fig. 3, lanes 3 and 4) compared to the control (Fig. 2 and Fig. 3, lanes 1 and 2). The transcript levels of OsGlu2, $T L P$, and $O S P R-10$ were increased at $4 \mathrm{~h}$ and slightly decreased at $8 \mathrm{~h}$, whereas $O s G l u 1$ gradually increased over time. OsRLK was at the same transcript levels at both $4 \mathrm{~h}$ and $8 \mathrm{~h}$ after treatment with fungal elicitor (Fig. 3, lanes 3 and 4). These results suggest that they can be used as molecular probes to further study elicitor-mediated signal transduction pathways.

The transcript levels of OsGlu1, OsTLP, and OsRLK were induced by application of JA (Fig. 3, lanes 5 and 6), and weakly induced by treatment with SA (Fig. 3, lanes 7 and 8) and ABA (Fig. 3, lanes 9 and 10), respectively. However, OsGlu2 and OsPR-10 were not induced by these phytohormones (Fig. 3, lanes 5-10). These transcriptional 


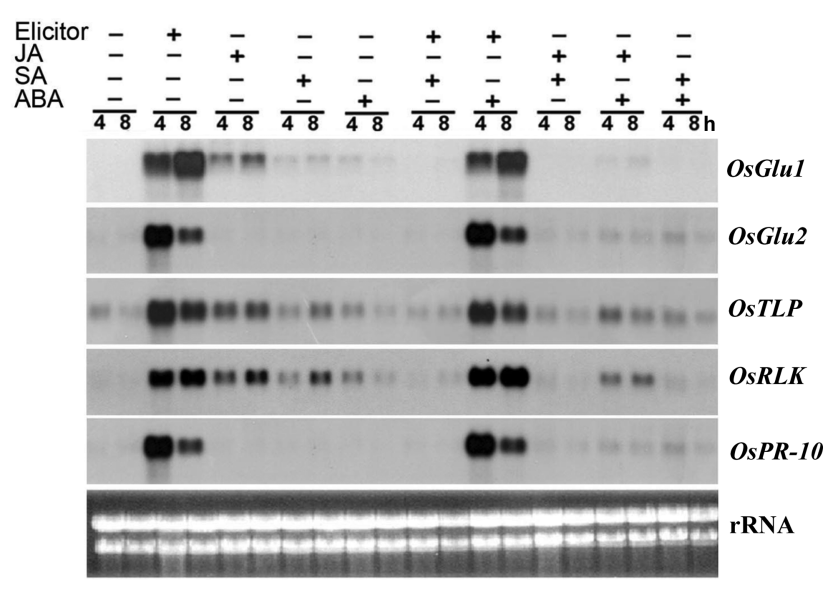

Fig. 3. Northern blot analyses of the OsGlu1, OsGlu2, OsTLP, $O s R L K$, and $O s P R-10$ transcripts in SCCs treated with elicitor and phytohormones. The cultured cells were either treated $(+)$ or untreated (-) with fungal elicitor $(50 \mu \mathrm{g} / \mathrm{ml})$, JA $(250 \mu \mathrm{M})$, SA (5 $\mathrm{mM})$, and ABA $(200 \mu \mathrm{M})$, separately or simultaneously. Total RNA $(20 \mu \mathrm{g})$ was extracted from SCCs inoculated with fungal elicitor and/or phytohormones. Each RNA sample was separated on a $1.2 \%(\mathrm{w} / \mathrm{v})$ formaldehyde-agarose gel and transferred onto a nylon membrane. The membranes were hybridized with the OsGlu1, OsGlu2, OsTLP, OsRLK, and OsPR-10 probed labeled with ${ }^{32} \mathrm{P}$ by using the Prime-a-Gene labeling system (Promega, Madison, USA).

expression patterns were consistent with protein expression patterns characterized by proteomic analysis in rice leaves after treatment with rice blast fungus or phytohormones (Kim et al., 2004a). OsPR-10 and OsGlu2 were slightly induced by each of the hormones in rice SCCs (Fig. 3, lanes 5-10). This result also was consistent with protein expression patterns reported by Kim et al. (2003b) using rice SCCs. However, protein expression levels of OsPR-10 and OsGlu2 were highly induced by JA in rice leaves (Kim et al., 2004a). This difference may be attributed to different tissues and organs having different sensitivities to both hormones.

SA and JA are involved in two major defense signaling pathways (Kunkel and Brooks, 2002), SA-dependent signaling pathways are effective against biotrophic fungi, bacteria and viruses, whereas SA-independent signaling pathway, which involves JA and ET, are predominantly effective against necrotrophic pathogens such as insects (Murray et al., 2002). However, M. grisea belongs to the hemibiotrophic pathogens, combining biotrophic and necrotrophic features (Perfect and Green, 2001; Munch et al., 2008), suggesting that these pathways are complicated crosstalk via both positive and negative effect mechanisms, controlling its defense responses according to the nature of the invading pathogen. Taken together, these data suggested that JA, SA, and ABA play a complex role for the induction of PR genes in rice SCCs.
SA suppresses fungal elicitor- or JA-induced transcriptional up-regulation of PR genes. Plant phytohormones play different roles in stress responses. They showed crosstalk between each other and fungal elicitors in previous studies (de Torres-Zabala et al., 2009; Flors et al., 2008). Interestingly, the fungal elicitor-induced transcript levels of PR genes were strongly inhibited by co-treatment with SA (Fig. 3, lanes 11 and 12), but only slightly affected by cotreatment with $\mathrm{ABA}$ when compared to fungal elicitor alone (Fig. 3, lanes 13 and 14). SA also significantly blocked the transcript levels of OsGlul, OsTLP, and OsRLK activated by JA (Fig. 3, lanes 15 and 16). Exogenous ABA slightly affected transcript levels of PR genes induced by JA (Fig. 3, lanes 17 and 18), and coapplication of SA and ABA did not interfere with the expression level of these PR genes (Fig. 3, lanes 19 and 20). Several genetic studies have showed evidence that SA antagonizes JA signaling in Arabidopsis thaliana (Durner et al., 1997) and tomatoes (Doares et al., 1995). JA, SA, and ABA are known to induce several PR genes, OsPRla, $O s P R 1 b$, and $O s P R 10$, but these transcripts induced by JA were down-regulated when $\mathrm{SA}$ and $\mathrm{ABA}$ were used simultaneously (Agrawal et al., 2000a, b; Rakwal et al., 2001). SA has been also shown to act synergistically with ET or JA to activate PR gene expression (Gu et al., 2000; $\mathrm{Xu}$ et al., 1994). However, several defense responses are regulated by ET and JA-dependant pathways (Dong 1998; Turner et al., 2002). This suggested that OsGlu1, OsTLP, and $O s R L K$ appear to belong to JA-dependent signaling pathway because of antagonistic effect between JA and SA. But it also seems to JA play a minor role in signaling pathway to induce PR gene and SA involves in inducing these genes independently.

Transcriptional regulation of PR genes by inhibitors. There is very limited information available on the signal transduction pathways of PR genes as they respond to biotic stresses. To understand how signal transduction is regulated, we co-applied several chemical inhibitors with fungal elicitors, including cycloheximide (CHX), staurosporine (Stau.), calyculin A (Cal A), and calcium ionophore A23187. After applying these chemicals independently or in combination with fungal elicitor to the SCCs, the expression profiles of PR genes were confirmed by Northern blot analysis. All chemical inhibitors were pre-inoculated 1 $\mathrm{h}$ prior to addition of the fungal elicitor, and each sample was harvested at 4 and $8 \mathrm{~h}$ post elicitor treatment. To investigate whether de novo synthesis of protein is required for induction of the PR genes by elicitor, we applied CHX to SCCs, which is a eukaryotic protein synthesis inhibitor. CHX strongly inhibited all transcript levels of PR genes in response to fungal elicitor, except for OsGlu2 (Fig. 4, lanes 


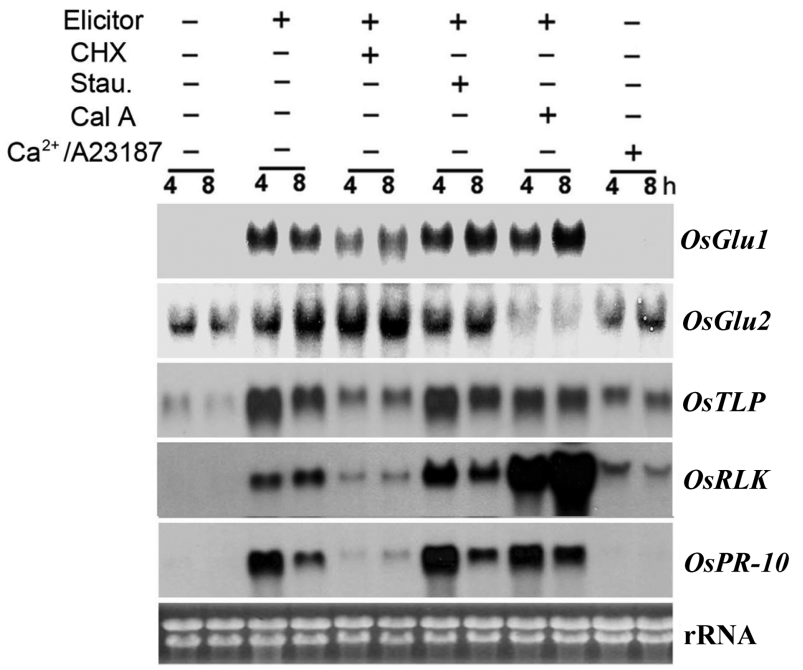

Fig. 4. Northern blot analyses to analyze the effect of inhibitors on OsGlu1, OsGlu2, OsTLP, OsRLK, and OsPR-10 expression. Cultured cells were either incubated $(+)$ or not incubated $(-)$ with $50 \mu \mathrm{g}$ elicitor, cycloheximide (CHX), staurosporine (Stau.), and calyculin A (Cal A). Each inhibitor $(1 \mu \mathrm{M}$ each except $20 \mu \mathrm{M}$ A23187 with $10 \mathrm{mM} \mathrm{Ca}{ }^{2+}$ ) was applied as a $1 \mathrm{~h}$ pretreatment before elicitor treatment. Total RNA $(20 \mu \mathrm{g})$ harvested from rice SCCs was prepared and transferred onto a nylon membrane. After hybridization in $65^{\circ} \mathrm{C}$ for $12 \mathrm{~h}$, the membranes were washed with $2 \times$ SSC containing $0.1 \%(\mathrm{w} / \mathrm{v})$ SDS for $30 \mathrm{~min}$, followed by additional washing with $0.2 \times \mathrm{SSC}$ containing $0.1 \%(\mathrm{w} / \mathrm{v}) \mathrm{SDS}$ for $10 \mathrm{~min}$. The signals were detected after being exposed on $\mathrm{X}$ ray film (Fuji, Japan) for 3 days at $-80^{\circ} \mathrm{C}$.

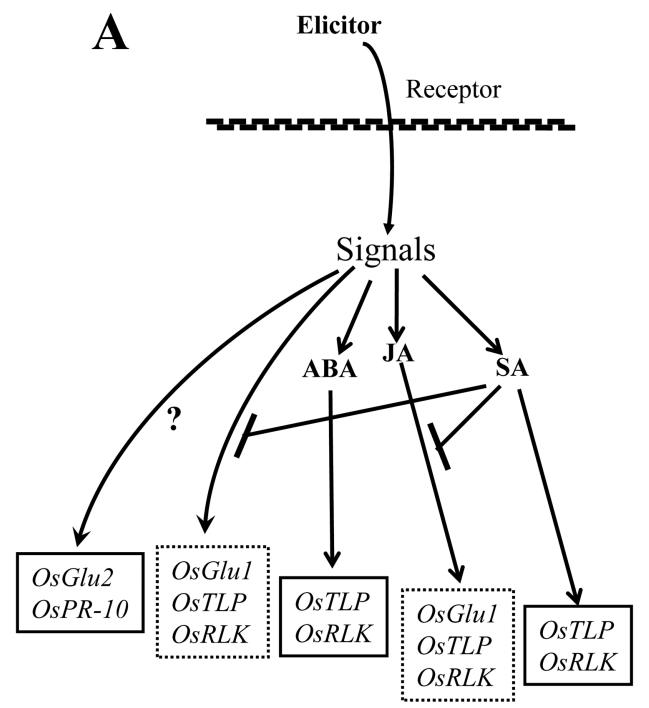

5 and 6). This result indicated that the de novo synthesis of OsPR-10, OsGlu1, OsTLP, and OsRLK proteins but not OsGlu2 is required.

PR gene expression was partially regulated by phosphorylation and dephosphorylation. In plant defense, protein phosphorylation and dephosphorylation is essential for pathway activation (Jonak et al., 2002; Ligterink et al., 1997) and protein kinase and phosphatase inhibitors have been used to explain the mechanisms of plants responses to stress (Rojo et al., 1998). We used specific inhibitors of protein kinases and phosphatases to examine whether phosphorylation or dephosphorylation events affect PR gene expression. Staurosporine, which was used as a serine/ threonine protein kinase inhibitor, was applied together with fungal elicitor to the callus. Only the $O s R L K$ was upregulated by staurosporine at $4 \mathrm{~h}$ (Fig. 4, lanes 7 and 8). Other PR genes were slightly influenced by staurosporine at $8 \mathrm{~h}$ compared to fungal elicitor alone (Fig. 4, lanes 7 and 8 ). We also treated the calli with elicitor as well as the inhibitor of protein phosphatase 1 and 2A, Calyculin A. The expression of OsGlu2 was suppressed, but OsRLK expression was strongly induced (Fig. 4, lanes 9, 10). These results indicated that the transcriptional regulation of PR genes by the elicitor was influenced differentially by either the protein kinase inhibitor or the phosphatase 1 and $2 \mathrm{~A}$ inhibitors. This is contrary to several other PR-proteins that

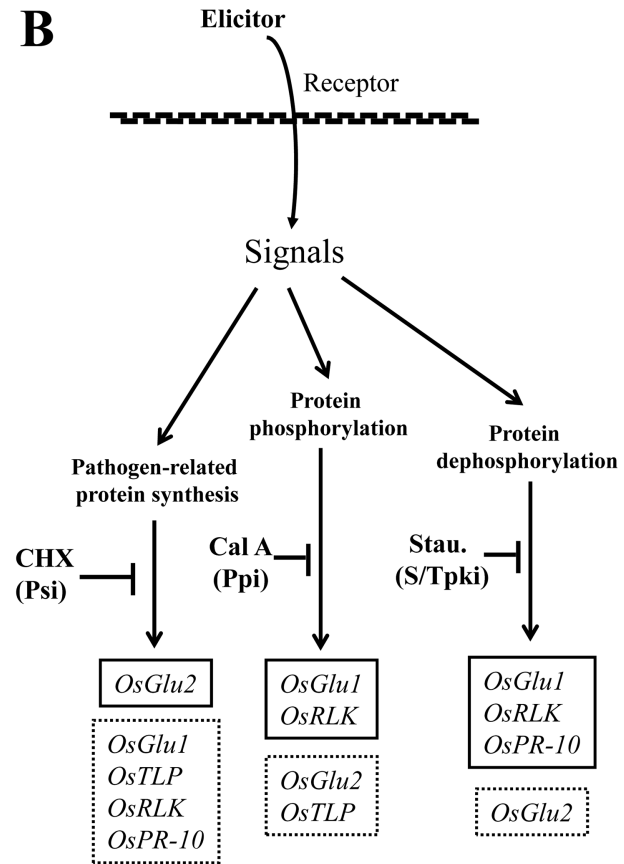

Fig. 5. Crosstalk model for several signaling pathways involved in the regulation of PR genes by fungal elicitor, phytohormones, and signaling inhibitors in rice SCCs. (Black rectangle; induction of PR genes, Dot rectangle; reduction of PR genes, Psi; protein synthesis inhibitor, Ppi; protein phosphatase inhibitor, S/Tpki; serine/threonine protein kinase inhibitor). 
are induced by phosphatase inhibitors (Agrawal et al., 2000a).

Calcium signaling showed crosstalk with defense regulation pathways. Calcium signaling is related to biotic or abiotic stress responses and development in various plants (Li et al., 2008; Song et al., 2008). Since in vivo calcium level changes have been reported to play an important role in defense signaling in plant cells, we investigated the role of calcium on PR gene expression. Treatment with $10 \mathrm{mM}$ calcium and a calcium ionophore, A23187 $\left(\mathrm{Ca}^{2+} / \mathrm{A} 23187\right)$, both activated the expression of OsGlu2, OsTLP, and OsRLK, even in the absence of the fungal elicitor (Fig. 4, lanes 11 and 12). This indicated that calcium actively participated in the induction of PR genes, but the transcript levels of OsGlu1 and OsPR-10 were not accumulated by $\mathrm{Ca}^{2+} / \mathrm{A} 23187$ as shown in Fig. 2 (Fig. 4, lanes 11 and 12). These results suggest that calcium ions are involved in a complex signal transduction pathway for elicitor perception and activation of individual genes.

\section{Conclusions}

In conclusion, we successfully isolated 31 fungal elicitorresponsive genes from SCCs treated with rice fungal elicitor employing the DH method. Among 31 genes, the transcript level of sixteen genes was increased at 4, 8, and $12 \mathrm{~h}$ following fungal biotic stress (Table 1, Fig. 2). In order to investigate the signal transduction pathways that lead to the activation of PR genes, we selected five isolated genes by DH which were OsGlu1, OsGlu2, OsTLP, OsRLK, and OsPR-10. From our results, both JA and SA are closely related with PR gene expression, and antagonistic effects were observed during signal transduction. However, ABA showed minimal effects on PR gene expression in the SCCs. Based on this, we predict considerable crosstalk between the fungal elicitor, JA and SA as shown in Fig. 5A.

A model showing the interaction between the fungal elicitor and biochemical inhibitors through transcriptional analysis is shown in Fig. 5B. The fungal elicitor may change the cell signaling network in rice SCCs and this signaling may differentially modulate transcriptional levels of PR genes including OsGlu1, OsPR-10, OsTLP, and OsRLK following treatment by biochemical inhibitors. Defense signal transduction is also related to calcium accumulation, which caused the expression of OsGlu2, $O S T L P$, and $O S R L K$. Protein dephosphorylation is necessary for the synthesis of OsGlu2. However, the inhibition of protein dephosphorylation caused increased accumulation of $O s R L K$ at the mRNA level. Therefore, the regulation of plant defense signaling is a complex process, related to kinase activation, protein modification, and calcium influx.

\section{Acknowledgments}

This work was supported by the Biogreen 21 (03-20080172) and Basic Science Research Program through the National Research Foundation of Korea (NRF) funded by the Ministry of Education, Science and Technology (20100014079, 2010-0004087), and the 2010 Specialization Project Research Grant funded by Pusan National University.

\section{References}

Acharya, B. R. and Assmann, S. M. 2009. Hormone interactions in stomatal function. Plant Mol. Biol. 69:451-462.

Adie, B. A., Pérez-Pérez, J., Pérez-Pérez, M. M., Godoy, M., Sánchez-Serrano, J. J., Schmelz, E. A. and Solano, R. 2007. $\mathrm{ABA}$ is an essential signal for plant resistance to pathogens affecting JA biosynthesis and the activation of defenses in Arabidopsis. Plant Cell 19:1665-1681.

Agrawal, G. K., Jwa, N. S. and Rakwal, R. 2000a. A novel rice (Oryza sativa L.) acidic PR1 gene highly responsive to cut, phytohormones, and protein phosphatase inhibitors. Biochem. Biophys. Res. Commun. 274: 157-165.

Agrawal, G. K., Rakwal, R. and Jwa, N. S. 2000b. Rice (Oryza sativa $\mathrm{L}$.) OsPR $1 \mathrm{~b}$ gene is phytohormonally regulated in close interaction with light signals. Biochem. Biophys. Res. Commun. 278:290-298.

Bari, R. and Jones, J. D. 2009. Role of plant hormones in plant defence responses. Plant Mol. Biol. 69:473-488.

de Torres-Zabala, M., Truman, W., Bennett, M. H., Lafforgue, G., Mansfield, J. W., Rodriguez Egea, P., Bogre, L. and Grant, M. 2007. Arabidopsis abscisic acid signalling pathway to cause disease. EMBO J. 26:1434-1443.

Doares, S. H., Narvaez-Vasquez, J., Conconi, A. and Ryan, C. A. 1995. Salicylic acid inhibits synthesis of proteinase inhibitors in tomato leaves induced by systemin and jasmonic acid. Plant Physiol. 108:1741-1746.

Dixon, R. A. and Lamb, C. J. 1990. Molecular communication in interactions between plants and microbial pathogens. Annu. Rev. Plant Physiol. Plant Mol. Biol. 41:339-367.

Dong, X. 1998. SA, JA, ethylene, and disease resistance in plants. Curr Opin Plant Biol. 1:316-323.

Durner, J., Shah, J. and Klessig, D. F. 1997. Salicylic acid and disease resistance in plants. Trends Plant Sci. 2:266-274.

Flors, V., Ton, J., van Doorn, R., Jakab, G., García-Agustín, P. and Mauch-Mani, B. 2008. Interplay between JA, SA and ABA signalling during basal and induced resistance against Pseudomonas syringae and Alternaria brassicicola. Plant J. 54:81-92.

Gu, Y. Q., Yang, C., Thara, V. K., Zhou, J. and Martin, G. B. 2000. Pti4 is induced by ethylene and salicylic acid, and its product is phosphorylated by the Pto kinase. Plant Cell 12:771-786.

Hamer, J. E. and Talbot, N. J. 1998. Infection-related development in the rice blast fungus Magnaporthe grisea. Curr. Opin. Microbiol. 1:693-697.

Heil, M. and Bostock, R. M. 2002. Induced systemic resistance 
(ISR) against pathogens in the context of induced plant defenses. Ann Bot (Lond). 89:503-512.

Hwang, D. H., Kim, S. T., Kim, S. G. and Kang, K. Y. 2007. Comprehensive analysis of the expression of twenty-seven beta-1, 3-glucanase genes in rice (Oryza sativa L.). Mol. Cells. 23: 207-214.

Hwang, S. H., Lee, I. A., Yie, S. W. and Hwang, D. J. 2008. Identification of an OsPR10a promoter region responsive to salicylic acid. Planta 227:1141-1150.

Ibeas, J. I., Lee, H., Damsz, B., Prasad, D. T., Pardo, J. M., Hasegawa, P. M., Bressan, R. A. and Narasimhan, M. L. 2000. Fungal cell wall phosphomannans facilitate the toxic activity of a plant PR-5 protein. Plant J. 23:375-383.

Jonak, C., Okrész, L., Bögre, L. and Hirt, H. 2002. Complexity, cross talk and integration of plant MAP kinase signalling. Curr. Opin. Plant Biol. 5:415-424.

Kim, S., Ahn, I. P. and Lee, Y. H. 2001. Analysis of genes expressed during rice-Magnaporthe grisea interactions. Mol. Plant-Microbe Interact. 14:1340-1346.

Kim, S. T., Cho, K. S., Kim, S. G., Kang, S. Y. and Kang, K. Y. 2003a. A rice isoflavone reductase-like gene, $O s I R L$, is induced by rice blast fungal elicitor. Mol. Cells 16:224-231.

Kim, S. T., Cho, K. S., Yu, S., Kim, S. G., Hong, J. C., Han, C. D., Bae, D. W., Nam, M. H. and Kang, K. Y. 2003b. Proteomic analysis of differentially expressed proteins induced by rice blast fungus and elicitor in suspension-cultured rice cells. Proteomics 3:2368-2378.

Kim, S. T., Kim, S. G., Hwang, D. H., Kang, S. Y., Kim, H. J., Lee, B. H., Lee, J. J. and Kang, K. Y. 2004a. Proteomic analysis of pathogen-responsive proteins from rice leaves induced by rice blast fungus. Magnaporthe grisea. Proteomics 4: 3569-3578.

Kim, S. T., Kim, S. G., Hwang, D. H., Kang, S. Y., Koo, S. C., Cho, M. J. and Kang, K. Y. 2004b. Expression of a saltinduced protein (SALT) in suspension-cultured cells and leaves of rice following exposure to fungal elicitor and phytohormones. Plant Cell Rep. 23:256-262.

Kim, S. G., Kim, S. T., Kim, S. K. and Kang, K. Y. 2008a. Gene expression profiling in rice infected with rice blast fungus using SAGE. Plant Pathol. J. 24:384-391.

Kim, S. T., Yu, S., Kang, Y. H., Kim, S. G., Kim, J. Y., Kim, S. H. and Kang, K. Y. 2008b. The rice pathogen-related protein 10 (JIOsPR10) is induced by abiotic and biotic stresses and exhibits ribonuclease activity. Plant Cell Rep. 27:593-603.

Kim, S. T., Kang, Y. H., Wang, Y., Wu, J., Park, Z. Y., Rakwal, R., Agrawal, G. K., Lee, S. Y. and Kang, K. Y. 2009. Secretome analysis of differentially induced proteins in rice suspensioncultured cells triggered by rice blast fungus and elicitor. Proteomics 9:1302-1313.

Koornneef, A., Verhage, A., Leon-Reyes, A., Snetselaar, R., Van Loon, L. and Pieterse, C. M. 2008. Towards a reporter system to identify regulators of cross-talk between salicylate and jasmonate signaling pathways in Arabidopsis. Plant Signal
Behav. 3:543-546.

Kunkel, B. N. and Brooks, D. M. 2002. Cross-talk between signaling pathways in pathogen defense. Curr. Opin. Plant Biol. 5:325-331.

Munch, S., Lingner, U., Floss, D. S., Liudwig, N., Sauer, N. and Deising, H. B. 2008. The hemibiotrophic lifestyle of Colletotrichum species. J. Plant Physiol. 165:41-51.

Murray, S. L., Denby, K. J., Berger, D. K. and Loake, G. J. 2002. Disease resistance signaling in Arabidopsis: applications in the study of plant pathology in South Africa. S. Afr. J. Sci. 98:161165.

Ligterink, W., Kroj, T., Nieden, U., Hirt, H. and Scheel, D. 1997. Receptor-mediated activation of a MAP kinase in pathogen defense of plants. Science 276:2054-2057.

Perfect, S. E. and Green, J. R. 2001. Infection structures of biotrophic and hemibiotro-phic fungal plant pathogens. Mol. Plant Pathol. 2:101-108.

Rakwal, R., Agrawal, G. K. and Yonekura, M. 2001. Light-dependent induction of OsPR-10 in rice (Oryza sativa L.) seedlings by the global stress signaling molecules jasmonic acid and protein phosphatase 2A inhibitors. Plant Sci. 161:469-479.

Rojo, E., Titarenko, E., Leon, J., Berger, S., Vancanneyt, G. and Sanchez-Serrano, J. J. 1998. Reversible protein phosphorylation regulates jasmonic acid-dependent and independent wound signal transduction pathway in Arabidopsis thaliana. Plant J. 13:153-165.

Seo, M., Nambara, E., Choi, G. and Yamaguchi, S. 2009. Interaction of light and hormone signals in germinating seeds. Plant Mol. Biol. 69:463-472.

Shinozaki, K. and Yamaguchi-Shinozaki, K. 2000. Molecular responses to dehydration and low temperature: differences and cross-talk between two stress signaling pathways. Curr. Opin. Plant Biol. 3:217-223.

Staskawicz, B. J., Ausubel, F. M., Baker, B. J., Ellis, J. G. and Jones, J. D. 1995. Molecular genetics of plant disease resistance. Science 268:661-667.

Talbot, N. J. 2003. On the trail of a cereal killer: Exploring the biology of Magnaporthe grisea. Annu. Rev. Microbiol. 57: 177-202.

Thomma, B. P., Penninckx, I. A., Broekaert, W. F. and Cammue, B. P. 2001. The complexity of disease signaling in Arabidopsis. Curr. Opin. Immunol. 13:63-68.

Ton, J., De, V. M., Robben, C., Buchala, A., Métraux, J. P., Van Loon, L. C. and Pieterse, C. M. 2002. Characterization of Arabidopsis enhanced disease susceptibility mutants that are affected in systemically induced resistance. Plant J. 29:11-21.

Turner, J. G., Ellis, C. and Devoto, A. 2002. The jasmonate signal pathway. Plant Cell 14:153-164.

Xu, Y., Chang, P., Liu, D., Narasimhan, M. L., Raghothama, K. G., Hasegawa, P. M. and Bressan, R. A. 1994. Plant defense genes are synergistically induced by ethylene and methyl jasmonate. Plant Cell 6:1077-1085. 